Portland State University

PDXScholar

Curriculum and Instruction Faculty Publications

and Presentations

Curriculum and Instruction

$1-2009$

\title{
Using the Lesson Study Approach to Plan for Student Learning
}

\author{
Susan J. Lenski \\ Portland State University \\ Micki M. Caskey \\ Portland State University, caskeym@pdx.edu \\ Vincent A. Anfara Jr. \\ University of Tennessee
}

Follow this and additional works at: https://pdxscholar.library.pdx.edu/ci_fac

Part of the Curriculum and Instruction Commons, and the Educational Assessment, Evaluation, and Research Commons

Let us know how access to this document benefits you.

\section{Citation Details}

Lenski, S. J., \& Caskey, M. M. (2009). Using the Lesson Study Approach to Plan for Student Learning. Middle School Journal, 40(3), 50-57.

This Article is brought to you for free and open access. It has been accepted for inclusion in Curriculum and Instruction Faculty Publications and Presentations by an authorized administrator of PDXScholar. Please contact us if we can make this document more accessible: pdxscholar@pdx.edu. 


\title{
Using the Lesson Study Approach to Plan for Student Learning
}

\author{
Susan J. Lenski \& Micki M. Caskey
}

The Lesson Study approach is a method of professional development that encourages teachers to reflect on their teaching practice through a cyclical process of collaborative lesson planning, lesson observation, and examination of student learning. This results-oriented professional development model is an ideal vehicle for improving instructional practice in middle schools. Characteristically, middle schools are (a) learning communities where teachers and students engage in active learning, (b) places with high expectations for every member of the community, and (c) organizational structures that support meaningful relationships (National Middle School Association, 2003). Middle school teachers have to know their students well—who they are and how they learn best—and use this information when planning instruction and assessing student performance (Jackson \& Davis, 2000). Most teacher planning focuses primarily on teacher actions rather than on student results (Ornstein, 1997). The Lesson Study approach, however, can provide an opportunity for middle school teachers to work together to strengthen the link between instructional planning and student learning.

\section{What is lesson study?}

Lesson Study is a "comprehensive and well-articulated process for examining practice" (Fernandez, Cannon, \& Chokshi, 2003, p. 171). The Lesson Study approach is the way Japanese teachers have studied their practice for decades. Educators from the United States who studied the reasons for Japan's high scores in mathematics concluded that Japan's success could be the result of their professional development model. These educators discovered that Japanese teachers had developed a way to examine student achievement using a method that Makoto Yoshida (1999) translated as "lesson study." Stigler and Hiebert (1999) introduced Lesson Study to teachers in North America in their book about international methods of instruction. Lesson Study is now one of the fastest-growing approaches to professional development in the United States (Lewis, Perry, Hurd, \& O'Connell, 2006).

\section{Theoretical perspectives}

Underpinning the Lesson Study approach is Situated Learning Theory (Lave \& Wenger, 1991), which advances the premise that learning is situated in the specific activity and is embedded within a particular context and culture. Lave and Wenger posited that learning is a social process in which individuals co-construct knowledge rather than transmit knowledge from one individual to the next. In the case of Lesson Study, the learning occurs as teachers exchange ideas and collaborate on lessons for their actual classrooms. Situated learning is a model of learning that transpires in a community of practice (Lave \& Wenger).

As teachers engage in the process of Lesson Study, they are collectively examining practice; they are functioning as communities of practice. "Communities of practice are groups of people who share a concern

This article reflects the following This We Believe characteristics: High expectations for every member of the learning community Students and teachers engaged in active learning - Organizational structures that support meaningful relationships and learning 
or a passion for something they do and learn how to do it better as they interact regularly" (Wenger, n.d.). The members of the community develop a shared practice, a repertoire of shared experiences and understandings. The Lesson Study approach helps teachers to form communities of practice around planning and teaching. In these communities, teachers construct, organize, share, and refine their knowledge of the lesson. Notably, the focus of Lesson Study remains the collaborative intellectual process rather than the output of isolated products such as a collection of model lessons (Chokshi \& Fernandez, 2004). This intellectual engagement is a hallmark of communities of practice, which "provide an avenue for teachers with common interests to interact with other professionals with similar interests to solve problems and improve practices" (Angelle, 2008, p. 56).

Developing and nurturing communities of practice require a number of conditions including the legitimatization of participation and provision of support (Wenger, 1998). Legitimizing participation entails giving members time to participate in collegial activities and creating an environment that acknowledges the value of communities. Providing support comes in the form of resources such as meeting space and outside experts. Not only are these cultural conditions critical for fostering and sustaining communities of practice, they also are imperative for creating an atmosphere for effective professional development.

\section{Communities of practice as professional development}

In recent years, educators and policymakers have expressed growing concerns about the effectiveness of traditional professional development (Penuel, Fishman, Yamaguchi, \& Gallagher, 2007). According to research conducted by Bryk and Schneider (2002) and Desimone (2002), professional development that centers on teacher learning communities rather than the more traditional "workshop" is more likely to be accepted by teachers and implemented in the classroom. Therefore, a growing trend in professional development is to move away from a workshop approach to one that implements some sort of community of practice and encourages teachers to solve educational problems together.

The research base on effective professional development indicates that there are predominantly six components that should be featured: (a) whether it actively fosters a reform style (i.e., study group, mentoring relationship, teacher research) rather than a traditional workshop; (b) whether it is of sufficient duration; (c) the degree to which it emphasizes the collective participation of groups of teachers from the same school, department, or grade level; (d) the extent to which it provides opportunities for active learning; (e) whether it promotes coherence by incorporating experiences that are consistent with teachers' goals and state standards; and (f) the degree to which it has a content focus (Desimone, Porter, Garet, Yoon, \& Birman, 2002). The Lesson Study approach is a good match for this type of professional development. Teachers using Lesson Study work as a team, either by grade level, subject area, or as an interdisciplinary group, to examine an instructional problem and determine how to apply the solution to current teaching goals. Lesson Study typically spans weeks or months as teachers meet to talk about the issue, plan the lesson, observe each other's teaching, and meet to discuss student learning. As teachers participate in Lesson Study groups, they actively discuss instructional interventions and share knowledge about how students will respond. Culminating from those discussions, teachers produce a lesson plan that is the result of collective wisdom and experience. Teachers then build on that collective wisdom as they watch each other teach and consider how best to engage students in learning.

\section{Research about planning}

The research on Lesson Study can be contextualized in the larger body of lesson planning research. The current thinking that lesson planning is a linear path that begins with a teaching objective is based on Tyler's work, which was published in 1949 (John, 2006). Tyler (1949) proposed that lesson planning should consist of four essential elements: educational purposes or objectives, classroom experiences to attain these purposes, effective organization of the experiences, and determining whether the purposes are attained. According to Yinger (1980), "Education, for the most part, adopted a rational model of planning based on models from economics and from national and city planning" (p. 108). The rational method of planning requires teachers to set goals, formulate alternatives, predict outcomes, and evaluate the effectiveness of reaching those goals. This linear, rational type of thinking became the basis for the predominant model of planning that is taught in teacher education programs today and is considered to be the prototype for lesson plans (Jalongo, et al., 2007). 
During the 1980s, a flurry of research was conducted about teacher planning that challenged the notion that teachers use linear lesson plans that begin with teaching objectives (Jalongo, Rieg, \& Helterbran, 2007). The results of this research indicated that teachers do not use a linear thought process when they plan. Instead, planning can be likened to the composing process in writing (Owen, 1991). Teachers use a pattern of "nested" decision making, focusing on activities rather than objectives, and they plan based on prior successful experiences and institutional elements such as the school schedule, availability of materials, and the interests and abilities of their students (Brown, 1988). When teachers plan, they engage in mental dialogues about teaching rather than writing down their plans. They think about their lessons and envision how they could implement those plans (Clark \& Peterson, 1986).

Recent research bolsters the argument that practicing teachers do not plan using what we have called the traditional lesson plan. According to Ornstein (1997), experienced teachers are holistic and intuitive when they plan. Strangis, Pringle, and Knopf (2006) found that teachers begin planning by thinking of activities or texts, not objectives. Sanchez and Valcarcel (1999) found that $78 \%$ of teachers in their study began lesson planning by thinking of the content knowledge, and only $22 \%$ began with objectives. Instead, teachers consider the lesson objectives as they teach, and the evaluate student learning. Ideas are shared, examined, negotiated, and decided upon. All of these interactions provide teachers with richer and more varied ideas than they could have generated by themselves. Research that has been conducted on Lesson Study indicates that it has strong potential for effective collaborative planning.

One example of research conducted in the United States studied 15 middle school teachers who used the Lesson Study approach as their primary method of professional development for six years (Vandeweghe \& Varney, 2006). The researchers reported that this approach helped the teachers form a vibrant learning community in which they examined their teaching practices. Fernandez (2002) investigated two groups of teachers, fourteen $\mathrm{K}-8$ teachers and nineteen middle school teachers, who used Lesson Study as their professional development focus. They found that teachers' intellectual engagement and collaborative work were benefits of using Lesson Study, but that there were also a variety of obstacles to this approach including having teachers find time to collaborate with their colleagues, overcoming their fear of having team members observe their teaching demonstrations, and critically analyzing their teaching practices.

In a second study of 16 U.S. teachers who were mentored by Japanese teachers in the Lesson Study approach, Fernandez, Cannon, and Chokshi (2003) concluded that to really benefit from using Lesson Study,

\section{When teachers plan, they engage in mental dialogues about teaching rather than writing down their plans.}

formats of plans vary according to the content of the lesson (Kagan \& Tippins, 1992). Because teaching is a complex process that is improvisational in nature, planning generally takes the form of a mental activity, which is a cyclical process that is successively recursive (Yinger, 1980).

\section{Planning using lesson study}

When teachers participate in a Lesson Study community, they verbalize the mental dialogue that usually occurs during individual planning. Further, the group interactions provide multiple ways to envision the lesson. As the teachers negotiate their final plan, they are able to examine a wider range of possibilities for lesson instructions, possible student responses, and how to teachers need to learn how to apply a critical lens to their examination of lessons the way a teacher researcher would. The same holds true for teacher candidates. Marble (2006) investigated eight teams of three student teachers each who had learned how to use Lesson Study to collaborate on planning. She found that teacher candidates were able to critically analyze their practice when they had the opportunity to look at their planning in this way.

Researchers in countries outside the United States have also conducted studies about the use of Lesson Study. In Indonesia, Marsigit (2007) conducted a pilot study regarding the introduction and use of Lesson Study with secondary mathematics teachers in three cluster sites (i.e., West Java, Central Java, East 
Java). Though initial findings revealed improvements in teaching practice, including student achievement, Marsigit cautioned that Lesson Study is only a starting point. In Hong Kong, Lee (2008) investigated secondary English teachers' professional development using a Lesson Study approach. He found that teachers developed subject knowledge and pedagogical skills, engaged in critical self-reflection, and were more attuned to students' learning needs; however, teachers also experienced increased levels of pressure from the additional workload and time commitment. In another case study, Law and Tsui (2007) studied how a team of university tutors, mentor teachers, and student teachers used Lesson Study to support student teachers' classroom teaching. Results indicated that this approach was a transformative professional development experience not only for the student teachers but also for the university tutors and mentor teachers.

Unquestionably, the research on Lesson Study is in its infancy. Lewis, Perry, and Murata (2006) discussed the need for further research on the topic. They recommend that there should be a three-pronged approach to developing the research base on Lesson Study. First, there have been several descriptive studies of Lesson Study projects. Lewis and associates(2006) recommended that more of these studies be conducted and published. In addition to descriptive studies, there needs to be an explication of the mechanics of Lesson Study. For example, what happens when teachers debrief a lesson needs to be examined. Finally, longitudinal studies that investigate how teachers using Lesson Study change their practice over time need to be conducted and reported.

In the next two sections, this column shifts from a review of salient research literature to a focus on the authors' own work with Lesson Study. After explaining how teams of middle school teachers participated in a Lesson Study project, we describe teacher candidates' experiences with this approach.

\section{Using lesson study with middle school teachers}

Our focus on Lesson Study was to determine whether this type of collaborative professional development could refocus teachers' thinking on student learning and develop sound instructional practices. We wondered whether the collaborative nature of the Lesson Study approach could help groups of teachers visualize how to

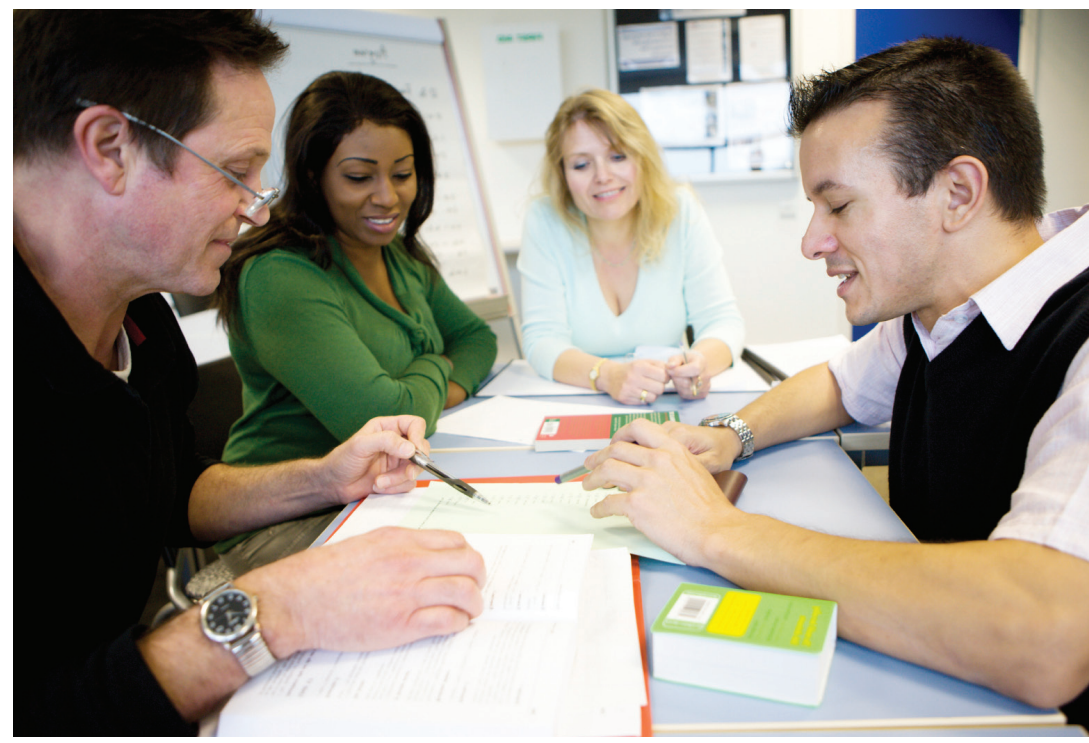

Middle level teachers collaborate in co-constructing knowledge to design learning activities for their students.

plan for student learning as they discussed and agreed upon the components of a lesson.

Teachers from three middle schools agreed to participate in the project and formed lesson study teams, ranging in size from two to eleven teachers. The teams consisted of a mix of content area teachers including language arts, math, science, and social studies teachers, as well as learning specialists (i.e., special education and ESOL teachers). Though the schools' geographic locations differed, all three schools served high-needs students. None of the schools had achieved adequate yearly progress (AYP) in language arts in the past year and all served populations that had at least $50 \%$ of the students receiving free and reduced-priced lunches. For two years, these lesson study teams met regularly to design, teach, observe, and evaluate "research lessons" that emphasized sound instructional principles and observations of student learning. The topics of their research lessons varied widely and included science lessons on genetics and sound; math lessons on algebraic equations; language arts lessons on a short story, prefixes, and roots; and social studies lessons on the plague and state rivers. After each school year ended, the lesson study teams from the three schools gathered at literacy symposia to share their lessons and experiences.

\section{Lesson Study in action}

In the Lesson Study approach, a community of teachers collaborates to plan a single lesson. The teachers talk about how a lesson fits with the overall school goals and 
what standards or objectives they want to achieve. To plan the details of the lesson, the teachers use a matrix like the one shown in Figure 1.

First, the teams agree on a lesson that furthers the students' progress toward a school or content goal. Then they outline the teachers' actions and brainstorm possible teacher comments. They script some of the comments that the teachers could use during the lesson at critical points. As they discuss teacher actions, they discuss potential student responses. This discussion tends to set in motion a process of reevaluating and revisioning the teacher actions, and the plan is revised until the teachers agree on their best course of action. As the teams discuss teacher actions and student responses, they also reflect on how to evaluate student learning. The teachers in this project were asked to consider four areas related to student learning: student engagement, student behavior, student learning, and student products.

The teachers in each of the three schools focused their plans primarily on student engagement. All of the teachers felt competent in classroom management and did not consider student behavior a major issue in their classrooms. They felt, however, that a lack of engagement prevented students from learning the concepts they were teaching. Each lesson, therefore, had ways (e.g., tests/ quizzes, written notes, or worksheet completion) that observing teachers could chart as evidence of student engagement through the lesson. Some teachers also included an informal check for understanding in their lessons. These informal observations of student learning took the form of having students volunteer to answer questions, looking at student work during the lessons, and listening to student small-group discussions.

The Lesson Study approach includes another powerful component: observing the lesson. Some of the teachers in our project were hesitant about having colleagues watch them teach. During Lesson Study, however, the observers do not evaluate teaching; they observe student learning. One teacher in each group taught the lesson, while the others observed students using agreed-upon criteria. For example, if the team agreed that students would be evaluated on the amount of participation in class discussion, the observers would record participation rates. Observers took note of other classroom events during instruction, but their primary task was to observe students.

After the lesson, the team reassembled and reflected on the lesson. The teacher shared his or her perceptions of how the lesson was received. The observers shared the data that they had collected. As a group, the teachers discussed what was successful in the lesson and the elements that could be strengthened. The teachers then revised the lesson, which could be taught again or made public by sharing it at a meeting or publishing it on a Web site.

Developing lessons using this collaborative approach to teaching produces exemplar lessons that can be published as models of instruction. (We provided our

Figure 1 Example of a Lesson Study planning matrix

\begin{tabular}{|c|c|c|c|}
\hline Research Lesson Steps & $\begin{array}{l}\text { Teacher Actions: } \\
\text { What the teacher is doing }\end{array}$ & $\begin{array}{l}\text { Student Actions: What the } \\
\text { students are doing and/or } \\
\text { expected student responses }\end{array}$ & $\begin{array}{l}\text { Evaluation: What data are } \\
\text { you collecting? How will you } \\
\text { collect it? What is the purpose } \\
\text { for the data being collected? }\end{array}$ \\
\hline $\begin{array}{l}\text { Connect the lessons to goals, } \\
\text { previous learning, and } \\
\text { standards. }\end{array}$ & $\begin{array}{l}\text { Tell students to spend five minutes } \\
\text { reviewing their notes from the } \\
\text { "talk back to the text" strategy } \\
\text { that they learned. Tell students to } \\
\text { reread them, answer questions, } \\
\text { or add thoughts. }\end{array}$ & $\begin{array}{l}\text { Students will open texts, look } \\
\text { through notes, make some } \\
\text { additional notes. Some talking } \\
\text { among peers is expected, but } \\
\text { it shouldn't interfere with overall } \\
\text { learning. }\end{array}$ & $\begin{array}{l}\text { \# of students engaged in task } \\
\text { \# of students talking with peers } \\
\text { and/or disrupting others } \\
\text { Collected through observation } \\
\text { for the purpose of determining if } \\
\text { students are on task }\end{array}$ \\
\hline Introduce the new concept. & $\begin{array}{l}\text { Explain that today students will use } \\
\text { what they know about the story } \\
\text { to infer, or intelligently guess, why } \\
\text { characters in the story act the way } \\
\text { they do. } \\
\text { Model inference for the students } \\
\text { using the first page of the story on } \\
\text { an overhead. }\end{array}$ & $\begin{array}{l}\text { Students will listen to the teacher. } \\
\text { There could be some side talking } \\
\text { or inattention, but the majority of } \\
\text { the students will be looking at the } \\
\text { teacher and quietly listening. }\end{array}$ & $\begin{array}{l}\text { \# of students watching the teacher } \\
\text { \# of students talking with peers } \\
\text { and/or disrupting others } \\
\text { Collected through observation } \\
\text { for the purpose of determining if } \\
\text { students are listening }\end{array}$ \\
\hline
\end{tabular}


teachers with the option of having their lessons posted on the Content Area Teacher Network Web site, http:// www.teachers.ed.pdx.edu.) The benefits of the Lesson Study approach, however, are not only the development of a demonstration lesson; teachers who collaborate on the development of the lesson learn from each other how to think about teaching and student learning.

\section{Mentoring teacher candidates}

In addition to introducing practicing teachers to the Lesson Study approach, we brought this approach into our teacher preparation program. Based on our knowledge of the program, we decided to incorporate Lesson Study into our middle school teacher candidates'

\section{Advice for teachers and administrators}

Becoming familiar with Lesson Study is an obvious initial step for teachers and administrators alike. To build an understanding of this approach, educators can engage in a book study (see Recommended Resources, p. 57), read journal articles (see References, pp. 56-57), view videos or DVDs (available at http://www.globaledresources. $\mathrm{com} /$ ), and consult with university faculty or regional education laboratories. Information and links to publications can also be found on Lesson Study Web sites including The Lesson Research Web Site hosted by the Education Department at Mills College (http://www. lessonresearch.net/) and The Lesson Study Research

\section{Teachers' intellectual engagement and collaborative work were benefits of using Lesson Study.}

methods courses. Teacher candidates have trouble relating to the kinds of lesson plans that they are taught in their teacher education programs, because these types of lesson plans tend to be far removed from what actual teachers do in the classroom (Maroney, \& Searcy, 1996). Teacher candidates are typically taught a linear, rational, ends-means sequence of lesson planning that begins with the objectives of the lesson (John, 2006). We taught our candidates a variety of ways to plan (e.g., differentiated lesson plan, inquiry-based lesson plan, PowerPoint lesson plan) including Lesson Study.

Our experiences introducing teacher candidates to collaborative planning were met with enthusiasm. Teacher candidates are novice planners and welcome input into their lesson planning. They also are accustomed to identifying their proposed actions, so they found the Lesson Study format easy to navigate. However, teacher candidates had much more difficulty than the practicing teachers did in thinking of ways to evaluate student learning. Consistent with research on the development of novice teachers, our teacher candidates were more focused on their own instruction than they were on how students responded (see John, 2006). As the teacher candidates moved into full-time student teaching, however, they were able to develop lessons and work samples that indicated growth on planning for both instruction and student learning.
Group at Teachers College/Columbia University (http:// www.tc.edu/centers/lessonstudy/).

Once teachers and administrators share a common understanding of Lesson Study, it is necessary to move from discussions to actually engaging in Lesson Study (Chokshi \& Fernandez, 2004). As with other innovative approaches, it is best to start Lesson Study with a small, interested group of teachers. These interested teachers, working as a learning community, are more likely to adopt the Lesson Study approach (Bryk \& Schneider, 2002; Desimone, 2002). Together the group can set realistic expectations for implementing Lesson Study in their school.

To engage effectively in Lesson Study will require certain conditions. First, teachers need time for genuine collaboration to occur (Vandeweghe \& Varney, 2006), which administrators will need to allocate in the school schedule. In middle schools, common planning time within the teachers' instructional day is an ideal venue for Lesson Study, though other regularly scheduled times for teacher collaboration can work. Second, teachers need to make collaboration routine. In Lesson Study, collaboration entails the collaborative planning, observing, and debriefing of lessons. Such collaborative work can encourage teachers to rely on their peers to inject vital feedback regarding the Lesson Study (Chokshi \& Fernandez, 2004). Similarly, the collaborative nature of Lesson Study can help teachers 


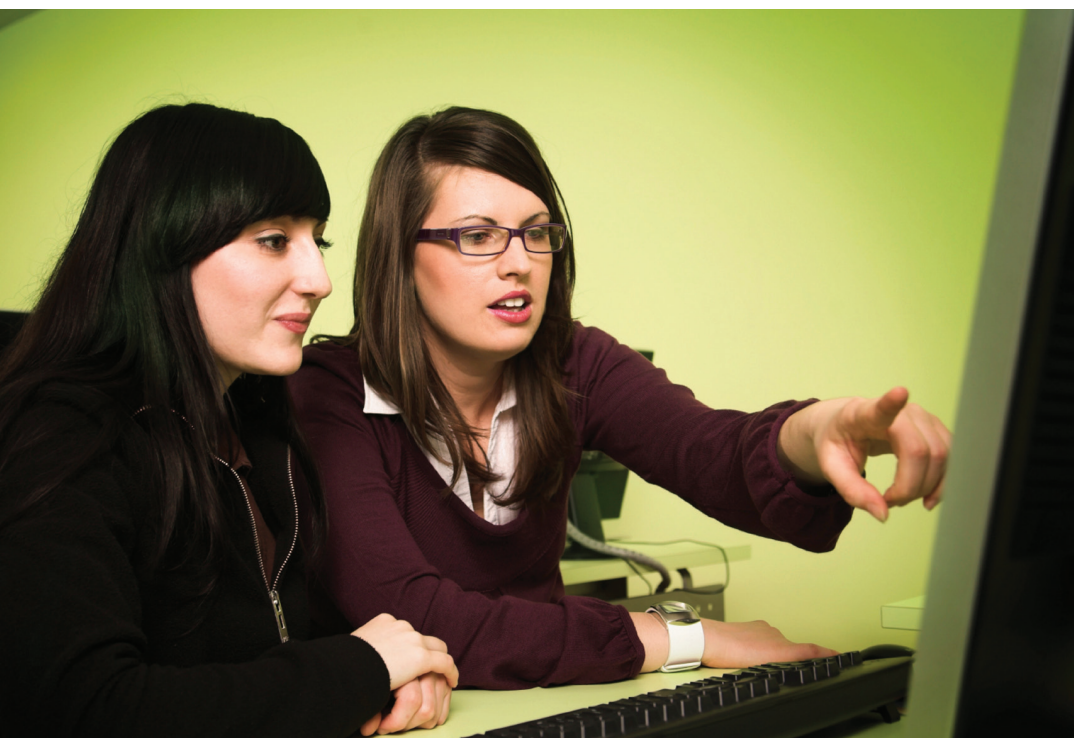

Lesson Study introduces preservice students to collaborative planning.

emphasize critical self-reflection and de-emphasize external evaluation (Lewis \& Tsuchida, 1998). Finally, teachers need to shift their attention to student thinking and learning when using the Lesson Study approach. When planning, teachers need to adopt the student lens (Fernandez, et al., 2003) and identify indicators of student engagement. During the observation of the lesson, teachers should focus on student work, engagement, and behavior, rather than focusing on the teacher's ability. By keeping the focus on the students, teachers can gain important insights into ways to improve their instructional practice.

\section{Conclusions}

"Effective planning is an essential element of good teaching and of promoting student achievement" (Jalongo, Rieg, \& Helterbran, 2007, p. 42). The Lesson Study approach is a way for teachers to engage in professional development leading to activities that promote instructional change. When teachers meet in professional learning communities to discuss planning, they become active participants in reform. Lesson Study has additional benefits by drawing teachers' attention to student learning as they think about their own instructional actions. A further advantage of Lesson Study is that it allows teachers to observe students during the teaching of a planned lesson. As teachers observe students, they begin to see teaching from the students' point of view. This new perspective can change deeply entrenched notions of instruction and result in better student learning.

\section{Acknowledgments}

This publication was made possible, in part, by a grant from Carnegie Corporation of New York and the U.S. Department of Education, Title IIA, University/School Partnership (USP) Program. The statements made and views expressed are solely the responsibility of the authors.

\section{References}

Angelle, P. S. (2008). Communities of practice promote shared learning for organizational success. Middle School Journal, 39(5), 52-58.

Brown, D. S. (1988). Twelve middle-school teachers' planning. Elementary School Journal, 89, 69-87

Bryk, A. S., \& Schneider, B. (2002). Trust in schools: A core resource for improvement. New York: Russell Sage Foundation.

Chokshi, S., \& Fernandez, C. (2004). Challenges to importing Japanese Lesson Study: Concerns, misconceptions, and nuances. Phi Delta Kappan, 85, 520-525.

Clark, C. M., \& Peterson, P. L. (1986). Teachers' thought processes. In M. C. Wittrock (Ed.), Handbook of research on teaching ( $3^{\text {rd }} \mathrm{ed}$.) (pp. 255-314). New York: Macmillan.

Desimone, L. (2002). How can comprehensive school reform models be successfully implemented? Review of Educational Research, 72, 433-479.

Desimone, L., Porter, A. C., Garet, M. S., Yoon, K. S., \& Birman, B. F. (2002). Effects of professional development on teachers' instruction: Results from a three-year longitudinal study. Educational Evaluation and Policy Analysis, 24(2), 81-112.

Fernandez, C. (2002). Learning from Japanese approaches to professional development: The case of lesson study. Journal of Teacher Education, 53, 393-405.

Fernandez, C., Cannon, J., \& Chokshi, S. (2003). A U.S.-Japan lesson study collaboration reveals critical lenses for examining practice. Teaching and Teacher Education, 19, 171-185.

Jackson, A. W., \& Davis, G. A. (2000). Turning points 2000: Educating adolescents in the 21st century. New York \& Westerville, $\mathrm{OH}$ : Teachers College Press \& National Middle School Association.

Jalongo, M. R., Rieg, S. A., \& Helterbran, V. R. (2007). Planning for learning: Collaborative approaches to lesson design and review. New York: Teachers College Press.

John, P. D. (2006). Lesson planning and the student teacher: Rethinking the dominant model. Journal of Curriculum Studies, 38 , 483-498.

Kagan, D. M., \& Tippins, D. J. (1992). The evolution of functional lesson plans among twelve elementary and secondary student teachers. Elementary School Journal, 92, 477-489.

Lave, J., \& Wenger, E. (1991). Situated learning: Legitimate peripheral participation. New York: Cambridge University Press.

Law, Y. K., \& Tsui, A. B. M. (2007). Learning as boundary-crossing in school-university partnerships. Teaching and Teacher Education, 23, 1289-1301.

Lee, J. F. K. (2008). A Hong Kong case of lesson study—Benefits and concerns. Teaching and Teacher Education, 24, 1115-1124. 
Lewis, C., Perry, R., Hurd, J., \& O'Connell, M. P. (2006). Lesson study comes of age in North America. Phi Delta Kappan, 88, 273-281.

Lewis, C., Perry, R., \& Murata, A. (2006). How should research contribute to instructional improvement: The case of lesson study. Educational Researcher, 35(3), 3-14.

Lewis, C., \& Tsuchida, I. (1998). A lesson is like a swiftly flowing river. American Educator, 22,(4),12-17, 50-52.

Marble, S. T. (2006). Learning to teach through lesson study. Action in Teacher Education, 28(3), 86-96.

Maroney, S. A., \& Searcy, S. (1996). Real teachers don't plan that way. Exceptionality, 6(3), 197-200.

Marsigit. (2007). Mathematics teachers' professional development through lesson study in Indonesia. Eurasia Journal of Mathematics, Science Ẽ Technology Education, 3(2), 141-144.

National Middle School Association. (2003). This we believe: Successful schools for young adolescents. Westerville, $\mathrm{OH}$ : Author.

Ornstein, A. C. (1997). How teachers plan lessons. High School Journal, 80, 227-238.

Owen, F. (1991). Teaching as a composing process. English Journal, $80(3), 57-62$.

Penuel, W. R., Fishman, B. J., Yamaguchi, R., \& Gallagher, L. P. (2007). What makes professional development effective? Strategies that foster curriculum implementation. American Educational Research Journal, 44(4), 921-958.

Sanchez, G., \& Valcarel, M. V. (1999.) Science teachers' views and practices in planning for teaching. Journal of Research in Science Teaching, 36, 493-513.

Strangis, D. E., Pringle, R. M., \& Knopf, H. T. (2006). Road map or roadblock? Science lesson planning and preservice teachers. Action in Teacher Education, 28(1), 73-84.

Stigler, J. W., \& Hiebert, J. (1999). The teaching gap: Best ideas from the world's teachers for improving education in the classroom. New York: Summit Books.
Tyler, R. (1949). Basic principles of curriculum and instruction. Chicago: University of Chicago Press.

Vandeweghe, R., \& Varney, K. (2006). The evolution of a schoolbased study group. Phi Delta Kappan, 88, 282-286.

Wenger, E. (n.d.). Communities of practice: A brief introduction. Retrieved August 12, 2008, from http://www.ewenger.com/ theory/index.htm

Wenger, E. (1998). Communities of practice: Learning as a social system. The Systems Thinker, 9(5), 2-3.

Yinger, R. J. (1980). A study of teacher planning. Elementary School Journal, 80(3), 107-127.

Yoshida, M. (1999). Lesson study: A case study of a Japanese approach to improving instruction. Doctoral dissertation, University of Chicago Department of Human Development.

\section{Recommended resources}

To learn more about Lesson Study and its use in schools, the following resources are recommended:

Northwest Regional Educational Laboratory. (2003). Lesson study: Crafting lessons together. Northwest Teacher, 4(3), 1-21. Portland, OR: Northwest Eisenhower Regional Consortium for Mathematics and Science. Available at http://www.nwrel.org/ msec/nwteacher/

Stepanek, J., Appel, G., Leong, M., Turner Mangan., M., \& Mitchell, M. (2007). Leading lesson study: A practical guide for teachers and facilitators. Thousand Oaks, CA: Corwin Press.

Wiburg, K., \& Brown, S. (2007). Lesson study communities: Increasing achievement with diverse students. Thousand Oaks, CA: Corwin Press.

Susan J. Lenski is a professor who teaches graduate courses in literacy and leadership at Portland State University, Oregon.

Micki M. Caskey is a professor in the Graduate School of Education at Portland State University, Oregon. She is chair of NMSA's Research Advisory Board and editor of Research in Middle Level Education Online. E-mail: caskeym@pdx.edu

Vincent A. Anfara, Jr., is associate professor and chair of educational leadership and policy studies at The University of Tennessee, Knoxville. He is the past chair of NMSA's Research Advisory Board and the executive director of AERA's Middle Level Education Research Special Interest Group. E-mail:vanfara@utk.edu

\section{Coming in March to Middle School Journal Readers}

\section{New Directions in Teaching Literacy}

- Assessment-Driven Writing Improvements

- Teen Voices Explore Cultural Diversity

- Multigenre Research Projects

- Assistive Technology and Universal Design

Plus other approaches to these important issues.

In your mailbox in early March!

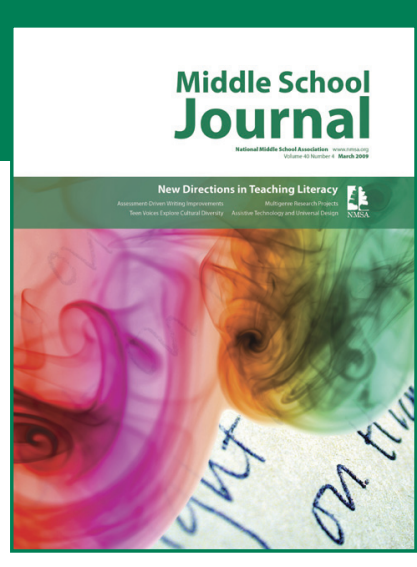

